PRZEGLĄD RUSYCYSTYCZNY 2020, nr 1(169)

DOI $10.31261 /$ pr.

OLGA I. WALENTINOWA

Rosyjski Uniwersytet Przyjaźni Narodów, Moskwa

(D) ORCID http://orcid.org/oooo-0002-8510-8701

MICHAIŁ A. RYBAKOW

Rosyjski Uniwersytet Przyjaźni Narodów, Moskwa

(DD ORCID http://orcid.org/oooo-0oo1-9444-3889

ALICJA PSTYGA

Uniwersytet Gdański, Gdańsk

(D) ORCID http://orcid.org/oooo-ooo1-6933-2132

\title{
NARUSZENIE FLEKSYJNOŚCI WE WSPÓŁCZESNYM JEZZYKU ROSYJSKIM Z PERSPEKTYWY TYPOLOGII SYSTEMOWEJ JĘZYKÓW GIENNADIJA P. MIELNIKOWA
}

Powszechność występowania innowacji językowych w językach naturalnych uzasadnia odniesienie tej klasy zjawisk do kategorii uniwersaliów językowych oraz uznanie ich za cechę typologiczną języków współczesnych. Dynamika rozwoju języków współczesnych, systematyczna rejestracja i opis zmian oraz - w konsekwencji - ich uwzględnienie w kolejnych wydaniach słowników normatywnych wykazuje także dynamikę w zakresie normy i kodyfikacji.

Procesy innowacyjne we współczesnym języku rosyjskim nasiliły się w latach 90. XX wieku, prowadząc do modyfikacji w obrębie całego systemu językowego. Zmiany zachodzące we współczesnym języku rosyjskim są przedmiotem zainteresowania wielu językoznawców, głównie w ujęciu normatywnym i dydaktycznym, dla których podstawowym problemem są rozbieżności między normą a uzusem oraz szeroko rozumiane zagadnienia kodyfikacji ${ }^{1}$. Jednakże interpretacja no-

1 Por. m.in. Культура русской речи, Труды Института русского языка им. В.В. Виноградова, вып. 13, А.Д. Шмелев (ред. выпуска), Москва 2017; Л.В. Рацибурская (red.), Новые тенденции в русском языке начала века, Издательство „Флинта-Наука”, Москва 2014. 
wych zjawisk w języku rosyjskim początku XXI wieku, w tym błędów stylistycznych i gramatycznych wyjątkowo częstych i równie często pojawiających się w licznych wypowiedziach w różnych odmianach i stylach funkcjonalnych współczesnego języka rosyjskiego, nie może sprowadzać się wyłącznie do skonstatowania obniżenia się poziomu kultury języka Rosjan. Wyjaśnienie przyczyn zachodzących zjawisk oraz prognozowanie dalszych zmian i ich konsekwencji w przypadku ustabilizowania się tej sytuacji można rozpatrywać w ramach typologii systemowej języków.

Typologia systemowa języków jako odrębny dział lingwistyki systemowej, którego zadaniem jest poszukiwanie determinantów i ustalenie stosunków determinacji, eksponuje i wyjaśnia systemowe uwarunkowania oraz wzajemne powiązania wszystkich poziomów systemu językowego - zgodnie z podziałem Wilhelma von Humboldta oraz późniejszymi modyfikacjami - w czterech podstawowych typach języków (izolującym, aglutynacyjnym, fleksyjnym i alternacyjnym). Kontynuatorem idei von Humboldta w drugiej połowie XX wieku i jednym z twórców współczesnej lingwistyki systemowej jest rosyjski lingwista Giennadij P. Mielnikow. Opracowana przez Mielnikowa ${ }^{2}$ systemowa typologia języków jest nauką o systemie - dyscypliną, która umożliwia integrację metodologii dowolnej dziedziny nauki i filozofii. W tym ujęciu typologia systemowa proponuje nie tylko klasyfikację typów języków ze względu na wybrane cechy, lecz także szczególne podejście do systemowości, ponieważ zgodnie z teorią Mielnikowa wszystkie znane klasyfikacje i typologie stanowią element jednej bardziej złożonej typologii systemowej (będącej - jak ją nazywa - typologią typologii). W ten sposób w ramach typologii systemowej dokonuje się synteza klasyfikacji morfologicznej i teorii stadialnej, dla których punktem wyjścia jest założenie wzajemnego ich dopełniania, nie zaś wykluczenia. Nie jest to więc propozycja nowa, ale przynosi ona inne rozumienie systemowości i spojrzenie na typologię, w których - koncentrując się na formach sensu i kulturowych wzorcach użycia języka - istotny jest człowiek i jego pozycja w społeczności etnicznej (ważne jest tu przyjęte przez Mielnikowa rozgraniczenie na mikro-, makro- lub mega-

2 Zob. Г. П. Мельников, Системная типология языков: Синтез морфологической классификации языков со стадиальной, Издательство РУДН, Москва 200о; Г. П. Мельников, Системная типология языков: Принципы, методы, модели, Наука, Москва 2003. 
kolektyw33), ale też w świecie, o którym mówi i który jest jego przestrzenią komunikowania w określonym przedziale czasowym. Sam autor sformułował istotę swego podejścia w następujący sposób:

исходным положением для системной лингвистики является не просто признание системности языка как социального явления, а утверждение, что язык входит в класс адаптивных (самонастраивающихся) и, следовательно, динамических систем ${ }^{4}$.

Zróżnicowanie typologiczne języków Mielnikow traktuje jako wynik procesów adaptacyjnych i dostosowania się systemów językowych do warunków komunikacji właściwych poszczególnym społecznościom językowym, zależnych od przyjętego stylu życia i preferowanych przez nie rodzajów działalności. Te uwarunkowania, zewnętrzne względem języka, traktowane są jako zewnętrzne determinanty budowy języka, które warunkują ustalone przez Mielnikowa determinanty wewnętrzne (z punktu widzenia komunikacji) czterech podstawowych typów morfologicznych:

Различия же между конкретными языковыми системами возникают в связи с тем, что каждая может иметь специфический способ функционирования, который и является ведущей грамматической тенденцией языка, его детерминантой5

Języki słowiańskie ${ }^{6}$, zwłaszcza wschodniosłowiańskie, z silnie zaznaczoną rolą fleksji, przez cały czas swego funkcjonowania wyróżnia-

3 Według Mielnikowa „[...] превращение макроколлектива в мегаколлектив, расширение границ территории, занимаемой носителями данного языка, ведет к росту значимости таких свойств языковой системы, которые делают ее наиболее совершенной прежде всего для общения между лично незнакомыми людьми, иначе любая социально общезначимая новость не сможет успешно распространиться по всей обширной территории расселения оседлого мегаколлектива" (Г. П. Мельников, Системная типология языков: Синтез морфологической классификации языков со стадиальной, Издательство РУДН, Москва 2000, с. 40).

4 Г.П. Мельников, Детерминанта - ведущая грамматическая тенденция языка, w: Фонетика, фонолония, грамматика (в честь 7о-летия А.А. Реформатского), Москва 1971, s. 359.

5 Г.П. Мельников, Конспект лекций по курсу „Введение в языкознание”. 19791980; суt. za: М.А. Рыбаков Развитие представлений о типологическом сходстве языков: от многомерной классификации Э. Сепира до системной типологии Г.П. Мельникова, w: О.И. Валентинова, В.Н. Денисенко, С. Ю. Преображенский, М.А. Рыбаков, Системный взгляд как основа филологической мысли, Языки славянской культуры, Москва 2016, с. 94.

6 Proces ten występuje również w innych językach słowiańskich. W odniesieniu do większości języków słowiańskich mówi się o wyjątkowej stabilności systemów 
ły się najwyższym stopniem stabilności typologicznej’. Skomplikowana syntetyczna morfologia słowiańska, dopuszczająca (jako sposób rozróżniania form gramatycznych) alternacje fonetyczne morfemów rdzennych i afiksalnych ${ }^{8}$, kształtowała się w jednorodnych społecznościach (kolektywach) prowadzących osiadły tryb życia, a jej celem było zapewnienie możliwości komunikacji w warunkach, gdy niemożliwy był przekaz interpersonalny bądź interakcje między jednym nadawcą a masowym odbiorcą z powodu poważnego zniekształcenia informacji ${ }^{9}$.

Ocena konsekwencji zachodzących zmian wymaga zatem uwzględnienia nie tylko czynników zewnętrznych, wpływających na kształtowanie się gramatycznej budowy fleksyjnej (np. liczebność społeczności językowej, stopień jej zróżnicowania społecznego, styl życia, warunki komunikacji), lecz także specyficznej struktury wewnętrznej języków fleksyjnych, która konkretyzuje się w określonych uwarun-

fleksyjnych, wskazując na kontynuację procesów wcześniejszych, ograniczanie wariantywności form podporządkowane prawu ekonomii językowej (por. zawartość poszczególnych tomów z serii „Najnowsze Dzieje Języków Słowiańskich”. Niektórzy badacze dowodzą jednak, że można mówić o znaczących ograniczeniach słowiańskiej fleksyjności (zob. m.in. H. Mieczkowska, Formy zaniku fleksyjności $w$ deklinacji stowackiej $w$ konfrontacji z polszczyzna, w: Z. Rudnik-Karwatowa (red.), Procesy innowacyjne $w$ językach słowiańskich, Prace Slawistyczne 114, SOW, Warszawa, 2003, s. 127-138; М. Я. Гловинская, Изменения в морфологии и синтаксисе, w: E. Širjaev (red.), Русский язык, Wydawnictwo Uniwersytetu Opolskiego, Opole 1997, s. 203-232.

7 Por. m.in. О.И. Валентинова, М.А.Рыбаков, Типологическая динамика языка как результат изменения ментальности его носителей, w: М. В. Пименова (red.), Язык и ментальность в диахронии: Материалы Всероссийского научного семинара, Издательство Владимирского государственного университета, Владимир, 2017, s. 58-70; seria „Najnowsze Dzieje Języków Słowiańskich" oraz będąca syntezą konfrontacji systemów języków słowiańskich „Komparacja Współczesnych Języków Słowiańskich” pod redakcją Stanisława Gajdy.

8 W. Humboldt, Über die Verschiedenheit des menschlichen Sprachbaues und ihren Einfluss auf die geistige Entwickelung des Menschengeschlechts, Druckerei der Königlichen Akademie der Wissenschaften, Berlin 1836.

9 Na ten problem zwracają uwagę Mielnikow oraz Danilenko: Г.П. Мельников, Системная типология языков: Синтез морфологической классификации языков со стадиальной, Издательство РУДН, Москва 2000; Г. П. Мельников, Системная типология языков: Принципы, методы, модели, Наука, Москва 2003; G.P. Melnikov, Systemology and linguistic aspects of cybernetics, OPA, Amsterdam 1988; A. Danylenko, The correlation of linguistic patterning and societal structures in systemic typology, „Studia Linguistica Universitatis Iagellonicae Cracoviensis”, t. 135 (2018), s. 81-96. 
kowaniach komunikacyjnych i wynika ze specyfiki przedstawienia zdarzenia $\mathrm{w}$ wypowiedziach formułowanych $\mathrm{w}$ języku określonego typu.

Obecnie w wypowiedziach należących do różnych odmian i stylów funkcjonalnych języka rosyjskiego, przede wszystkim w publicznym dyskursie medialnym, można zaobserwować zmiany w zakresie fleksyjności, co przejawia się w zaburzeniu zgodności przypadków we frazach nominalnych, w użyciu konstrukcji z kilkoma członami w dopełniaczu, których semantyka jest niejasna, w pojawieniu się liczby mnogiej rzeczowników abstrakcyjnych, w braku rozróżnienia kategorii strony czasownika, w braku korelacji między subiektem imiesłowu przysłówkowego a subiektem orzeczenia, w masowym użyciu przydawek połączonych związkiem zgody (kongruentnych). Zmiany te zachodzą przede wszystkim w uzusie, jednak ich powszechny charakter, o czym świadczy pojawianie się określonych form fleksyjnych (jak w przykładach wskazanych poniżej) również w przygotowanych wypowiedziach oficjalnych, skłania do refleksji nad tym zjawiskiem nie tylko w kontekście obowiązującej normy językowej. Analiza zgromadzonego przez autorów artykułu materiału językowego i spojrzenie na wskazane zjawisko z perspektywy cech typologicznych współczesnego języka rosyjskiego (podkreślmy - typu fleksyjnego) wprawdzie nie może przynieść pełnego obrazu zmian w zakresie fleksji rosyjskiej ${ }^{10}$, ale, jak sądzimy, pozwala na ich ocenę z perspektywy systemu i typologii systemowej zgodnie z ujęciem Mielnikowa.

Przyjrzyjmy się zatem poszczególnym przypadkom, potwierdzającym problem zmian w zakresie fleksyjności języka rosyjskiego:

1. Powszechne naruszenie zasady kongruencji - zgodności w zakresie przypadka członów grupy imiennej, którego konsekwencją jest osłabienie funkcji przypadka - burzy wypracowaną przez język fleksyjny technikę prognozowania, pomagającą słuchaczowi (odbiorcy) na podstawie usłyszanej informacji choćby w nieznacznym stopniu domyślić się, jakie formy gramatyczne będą stosowane w dalszej części wypowiedzenia. W konsekwencji nie są wykorzystywane wypracowa-

${ }^{10} \mathrm{O}$ zmianach $\mathrm{w}$ zakresie fleksji współczesnego języka rosyjskiego w kontekście statusu rosyjskich elit kulturalnych i intelektualnych oraz wpływu społeczeństwa na kształtowanie normy zob. np. artykuł О.И. Валентинова, М.А. Рыбаков, А. Пстыга, Типологическая сохраненность русского языка как необходимое условие культурной и интеллектуальной самоидентификации россйского общества, „Вопросы теории и практики журналистики” („Theoretical and Practical Issues of Journalism", t. 7, nr 3, 2018, s. 418-428. 
ne sposoby wyrażania określonej treści w relacjonowaniu zdarzenia, będące następstwem rozwoju techniki przewidywania w przekazie informacji w językach fleksyjnych. Sytuację tę ilustrują sformułowania zaczerpnięte $\mathrm{z}$ ministerialnych rozporządzeń i ulotek informacyjnych w sferze oświaty, kultury i ochrony zdrowia: Об изменении в состав в 11 рабочих инвентаризационныхкомиссиях (w tytule rozporządzenia); несколько интереснейших памятников в стиле конструктивизм; организоватьконтроль за посещаемостью сотрудников занятий.

Jeśli odzwierciedlenie rozwijającego się zdarzenia zapewnia formalnie jednoznaczna opozycja znaków stymulujących to zdarzenie (forma czasownika), sprawcę tego zdarzenia (rzeczownik w mianowniku), uczestnika zdarzenia doświadczającego na sobie skutki tego zdarzenia (rzeczownik w bierniku), innych uczestników zdarzenia (rzeczowniki w przypadkach zależnych) itd., a przypadek (jako kategoria i określony paradygmat) jest najprostszym skondensowanym zdaniem i w istocie umożliwia zagęszczenie semantyki pierwotnego tekstu, pozostając przy tym formalnym środkiem jego spójności semantycznej ${ }^{12}$, to osłabienie funkcji przypadka i naruszenie określonej opozycji formalnej znaków sprawia, że związek przyczynowo-skutkowy między poszczególnymi etapami przedstawianego zdarzenia staje się niejasny. Tym samym słuchacz zostaje pozbawiony możliwości prognozowania form gramatycznych kolejnych informacji w dalszych etapach relacjonowanego zdarzenia i nie może zweryfikować swych przypuszczeń.

2. Związek przyczynowo-skutkowy następujących po sobie etapów zdarzenia traci wyrazistość również z powodu użycia konstrukcji z kilkoma dopełniaczami. W tej sytuacji same relacje semantyczne między poszczególnymi komponentami stają się niejednoznaczne. Świadczą o tym sformułowania typu: Об утверждении плана

${ }^{11}$ Rozstrzeleniem zostały wyróżnione formy niepoprawne.

${ }^{12}$ Zob. Д.М. Гзгзян, Функция предлога в составе семантической структуры высказывания: автореф. дисс. канд. филол. наук (10.02.01), Университет дружбы народов им. П. Лумумбы, Москва 1989; А. Ф. Дремов, Системная теория падежа и предлога в практике преподавания русского языка как иностранного, „Мир русского слова” 2001, $\mathrm{nr}$ 1-4; Г.П. Мельников, А.Ф. Дремов, Уровни связности текста, актуальная предикация и падеж с позиций системной лингвистики, w: О.А. Крылова (red.), Синтаксис и стилистика, Москва 1984, s. 49-70; М.А. Рыбаков Развитие представлений о типологическом сходстве языков: от многомерной классификации Э. Сепира до системной типологии Г.П. Мельникова, w: О. И. Валентинова, В. Н. Денисенко, С. Ю. Преображенский, М.А. Рыбаков, Системный взгляд как основа филологической мысли..., с. 17-136. 
мероприятий концепции цуелевой программы (nazwa rozporządzenia wewnętrznego w instytucji oświaty); Федерация психологов образования России (nazwa stowarzyszenia psychologów).

3. O deformacji typologicznej w najnowszym języku rosyjskim świadczy pojawienie się form liczby mnogiej rzeczowników abstrakcyjnych (i rozszerzenie paradygmatu ich odmiany). Pojawiają się więc w wypowiedziach oficjalnych formy typu: активности, взаимодействия, коммуникации, озабоченности. W ten sposób do fleksji rosyjskiej przenika typowa dla języków analitycznych wieloznaczność leksykalna, ponieważ wiele wyrazów ma w nich jednocześnie znaczenia konkretne i znaczenia abstrakcyjne, a zatem, zależnie od woli mówiącego, rzeczowniki te mogą przybierać dla znaczeń konkretnych formy liczby mnogiej. W ten sposób w języku rosyjskim ginie wartość słowa jako abstractum, jego znaczenie podlega konkretyzacji.

4. W kategoriach naruszenia podstaw fleksyjności rosyjskiej należy rozpatrywać brak koreferencji subiekta imiesłowu przysłówkowego z podmiotem, jaką można zaobserwować w wypowiedziach Rosjan. Np. Играя в казино, трудно не быть убитьмм (w wуроwiedzi pracownika prokuratury); Прочитав статью, у меня возник вопрос (replika studenta); Руководствуясь приказом ректора, бъло принято решение (z korespondencji służbowej pracowników szkoły wyższej).

Obecnie, co warto podkreślić, brak zgodności między subiektem wyrażenia z imiesłowem przysłówkowym a podmiotem jest interpretowany jako wynik oddziaływania na język rosyjski cech typologicznych języka angielskiego. Interpretacja ta winna jednak uwzględniać wcześniejsze zmiany zachodzące w języku rosyjskim. Na błędny charakter konstrukcji typu идучи я в школу, встретился со мной приятель zwracał bowiem uwagę jeszcze Michaił Łomonosow. Wcześniej uznawane były one za wpływ bilingwizmu rosyjsko-francuskiego i dlatego przez długi czas rozpatrywano je jako galicyzmy. Te same konstrukcje - jak dowiódł Franc Miklosich ${ }^{13}$, co potwierdzili Aleksandr Potiebnia ${ }^{14}$, Dmitrij Owsianiko-Kulikowski ${ }^{15}$, Alek-

${ }^{13}$ F. Miklosich, Vergleichende Grammatik der slawischen Sprachen: Bd. Syntax, W. Braumüller, Wien 1868-1874.

${ }^{14}$ А.А. Потебня, Из записок по русской грамматике, Д.Н. Полуехтов, t. 1, Харьков 1888.

15 Д.Н. Овсянико-Куликовский, Синтаксис русского языка, Издание Д. Е. Жуковского, Санкт-Петербург 1902. 
sandr Pieszkowski ${ }^{16}$ - funkcjonowały $\mathrm{w}$ języku rosyjskim znacznie wcześniej, nim język rosyjski podporządkował się wpływom obcym. Oznacza to, że oceniając charakter zmian typologicznych, trzeba brać pod uwagę aspekt historyczny.

W tym miejscu należy także odwołać się do obserwacji Piotra Bicylliego ${ }^{17}$, który również dostrzega częste występowanie tego typu zwrotów w utworach Aleksandra Gribojedowa, Aleksandra Puszkina, Fiodora Dostojewskiego, Iwana Turgieniewa, Lwa Tołstoja czy Nikołaja Niekrasowa - autorów tych czasów, kiedy klasyczny język rosyjski już się ukształtował. Por. m.in.: „Въехавши на пригорок..., вдруг предстали пред нами две горы” (Грибоедов, Писъмо к Бегичеву); „Читая Шекспира и библию, св. дух иногда мне по сердцу...” (Пушкин, Писъмо к Вяземскому); „Приехав в Семипалатинск, встретили меня хлопоты по устройству квартиры” (Достоевский, Писъмо к Врангелю).

Zaproponowana przez Bicylliego interpretacja typologiczna występujących w twórczości klasyków literatury rosyjskiej zwrotów z pominięciem koreferencji subiekta formy imiesłowowej z podmiotem miała jednakże inny charakter. Autor ten przypuszczał (z czym trudno się nie zgodzić), że w tym przypadku chodzi o skrajny przejaw syntetyzmu językowego, który pojmował jako dążenie do tworzenia fraz pod względem formy wewnętrznej równych jednemu słowu ${ }^{18}$. Por.:

Их „неправильность.” означает их неразложимость. Они лучше, точнее выражают то, что находится в сознании говорящего, чем „правильные”, каких требовал Ломоносов. Для него, говорящего, сам, идущий по улице, его движение по улице, его встреча с приятелем, приятель - все это лишь отдельные стороны одного и того же, целостного, предмета восприятия, один образ; а значит, указание на него, выраженное в форме, не поддающейся разложению, в действительности является наиболее удачным образом - символом, воспринимаемым скорее как одно слово, чем как предложение. А тот факт, что слушатель, или читатель, принимает сказанное ему так, как этого хочет говорящий, свидетельствует, что и в его сознании высказанное подобным способом создалось таким же, каким оно было в сознании говорящего ${ }^{19}$.

${ }^{16}$ А.М. Пешковский, Русский синтаксис в научном освещении, Языки славянских культур, Москва 2001.

${ }^{17}$ П.М. Бицилли, Заметки о некоторых особенностях развития русского литературного языка, w: tegoż, Избранные труды по филологии, ред. В. Н. Ярцева, Москва 1996, с.249-340.

${ }^{18}$ Por. „[...] тяготение к созданию фраз, являющихся по своей внутренней форме каждая - одним словом”. П.М. Бицилли, Заметки о некоторых особенностях..., s. 294.

19 Tamże. 
Struktury syntaktyczne, które w bardziej sprzyjających warunkach społeczno-kulturowych można byłoby uznać za relikty polisynkretyzmu (inkorporacji), obecnie odbierane są jako kalki konstrukcji angielskich. Jednakże masowe i nader częste użycie angielskich zapożyczeń leksykalnych oraz innych komponentów strukturalnych ${ }^{20}$ nie wynika z dobrej znajomości języka angielskiego i osiągnięcia sprawności komunikacyjnej na wszystkich poziomach. Raczej odwrotnie: z perspektywy komunikacji należałoby odnieść je do wypowiedzeń zawierających struktury okazjonalne. W praktyce oznacza to, że ustalenie znaczenia wymaga niekiedy znacznego poszerzenia kontekstu. Przekazanie złożonych sensów w określonych uwarunkowaniach komunikacyjnych wydaje się zatem albo utrudnione, albo nie zostaje właściwie odebrane. Jednakże, co podkreśla Siergiej J. Preobrażenski, rusycyści nie dostrzegają tych przemian w gramatyce rosyjskiej, lecz - kontynuując dyskurs normatywny - oceniają jedynie poszczególne użycia wyrazów ${ }^{21}$.

Poszerzenie zakresu użycia zwrotów z imiesłowem przysłówkowym prowadzi jednocześnie do wyparcia charakterystycznych dla języków fleksyjnych zdań złożonych podrzędnie, a w konsekwencji do wzrostu analityzmu. Jeśli bowiem cechą zwrotów imiesłowowych jest ich dopasowanie (związek przynależności) do pozostałej części wypowiedzi (z punktu widzenia semantyki jest to bardziej niezależna pozycja), to dla zdania złożonego podrzędnie właściwe jest wyraźne wskazanie na charakter związków logicznych między dwoma predykatami przy jednoznacznym zaznaczeniu ich hierarchii. Swoboda w zakresie koreferencji zwrotów imiesłowowych wyraża natomiast okazjonalną semantykę konstrukcji gramatycznej i podkreśla nie powiązanie zdarzeń jako ich następstwo, lecz ich współistnienie w czasie i przestrzeni.

${ }^{20} \mathrm{Na}$ to zjawisko zwraca uwagę m.in. Alicja Pstyga, wskazując na paralelny charakter powoływania okazjonalnych struktur słowotwórczych z komponentem -ing (-инг) w języku polskim i rosyjskim przy oczywistych ograniczeniach ekwiwalencji przekładowej wybranych konstrukcji - zob. A. Pstyga, Problemy interpretacji tekstu: integracja metodologiczna we współczesnym językoznawstwie słowiańskim, w: E. Koriakowcewa (red.), Współczesne językoznawstwo słowiańskie. Teoria i metodologia badań, t. 2: Metody analizy i opisu jednostek leksykalnych i tekstowych, Wydawnictwo UPH w Siedlcach, Siedlce 2016, s. 103-111.

${ }^{21}$ Zob. sformułowanie autorskie: „русисты успешно не замечают подвижек в русской грамматике, но продолжают живо обсуждать нормативность отдельных словоупотреблений.”(С.Ю. Преображенский, Системный анализ стиха, w: О.И. Валентинова, В.Н. Денисенко, С. Ю. Преображенский, М.А. Рыбаков, Системный взгляд как основа филологической мысли..., s. 311). 
Tego rodzaju innowacje we współczesnym języku rosyjskim są spowodowane zmianą warunków komunikacji społecznej ${ }^{22}$, przede wszystkim rosnącym zróżnicowaniem językowym społeczeństwa.

5. Kolejnym charakterystycznym zjawiskiem gramatycznym w wypowiedziach współczesnych Rosjan są błędy wynikające z nierozpoznawania kategorii strony czasownika, co również wiąże się z fleksją i semantyką. Świadczą o tym wybrane przykłady pochodzące z telewizyjnych programów informacyjnych:

Школа выражает благодарность за участие в профессиональноориентируе мом мероприятии. Powinno bус́: Школа выражает благодарность за участие в профессионально-ориентирующем мероприятии (ponieważ przedsięwzięcie ma wpłynąć na dokonywany przez uczniów wybór profesji; samo zaś przedsięwzięcie - ros. мероприятие - żadnej orientacji nie wymaga).

Несмотря на это, женщина смогла проникнуть на запрещающую территорию. Powinno być: Несмотря на это женщина смогла проникнуть на запретную территорию (территория - pol. terytorium nie może niczego zabraniać, a zatem nie może być zgodności z formą fleksyjną imiesłowu przymiotnikowego).

Błędy w zakresie kategorii gramatycznej strony czasownika wynikają nie z wartości samej kategorii, która występuje zarówno w językach syntetycznych (na przykład w języku łacińskim jest wyrażana poprzez odrębny system fleksyjny), jak i analitycznych (m.in. w języku angielskim), lecz z desemantyzacji formalnych wyróżników kategorii strony. Prawdopodobnie pospieszna i bezrefleksyjna wypowiedź nie pozwala mówiącemu na dokładne (zgodne z normą) zastosowanie morfemów gramatycznych. Sens w przybliżeniu odpowiada więc całej sytuacji i wprawdzie użycie afiksów jeszcze z przyzwyczajenia mówiący odczuwają jako niezbędne, lecz sens tych afiksów nie jest już dla nich tak wyrazisty.

6. Problemem staje się użycie przydawki przymiotnej w znaczeniach tradycyjnie wyrażanych przez rzeczownik w funkcji atrybutywnej: w tym przypadku związana składnią zgody (kongruentna) przydawka zdecydowanie wypiera użycie przypadków zależnych rzeczownika w funkcji atrybutywnej, nie rekompensując jednak wyrażanych przez nie relacji semantycznych ${ }^{23}$. Por. np. często spotykane

${ }^{22}$ Por. E. Širjaev (red.), Русский язык, seria Najnowsze Dzieje Języków Słowiańskich, S. Gajda (red.), Wydawnictwo Uniwersytetu Opolskiego, Opole 1997.

${ }^{23}$ Problem ten szerzej analizuje Olga Walentinowa: О. И. Валентинова, Системный подход к исследованию текста и стиля, w: О. И. Валентинова, В. Н. Де- 
w mediach sformułowania: академическое руководство zamiast руководство Академии наук; академический храм zamiast храм при Духовной академии; дипломатический маэстро zamiast маэстро в области дипломатии (о przewodniczącym Federacji Rosyjskiej w ONZ).

Typowy dla języka rosyjskiego porządek wyrazów narusza będące odwzorowaniem angielskiej składni przesunięcie przydawki w stronę lewą (zgodnie z terminologią składni generatywnej). Tendencja ta obejmuje całe zwroty przydawkowe i sprawia, że wypowiedzi są mało komunikatywne, jak w zdaniu: Водитель сбившей маиину с детьми „Газели” мог уснуть за рулём [Новости Newsru.com (25.03.2017)].

Rozdzielenie grupy imiennej водитель ... „Газели” dodatkowo wpływa na stopień utraty sensu wypowiedzenia. Ogólnej tendencji odpowiadałoby również pojawienie się w tej wypowiedzi niepoprawnych sformułowań газельный водитель і детская машина, które spowodowałyby jeszcze większe zagęszczenie sensów. Zamiana dopełniacza przydawką przymiotną w takich wypadkach wprowadza do przymiotnika nieistniejący sens, deformując jego znaczenie leksykalne. $\mathrm{W}$ zaistniałej sytuacji rozpowszechnionego użycia kongruentej przydawki nie należy interpretować jako przejawu fleksyjności, ponieważ kongruentna przydawka zaczyna zastępować wypracowane przez język możliwości wyrażania szczegółowych odcieni znaczeniowych relacji atrybutywnych, które powinny być wyrażane za pomocą bezprzyimkowych bądź przyimkowych form przypadków zależnych rzeczownika. Utrudniając lub uniemożliwiając więc wyrażenie subtelnie zróżnicowanych sensów - nawet przy istotnym poszerzeniu kontekstu - związek zgody słowa określającego z określanym pod względem rodzaju, przypadka i liczby wbrew oczekiwaniom nie wpływa na zwiększenie możliwości skutecznego przekazania informacji w złożonych uwarunkowaniach komunikacyjnych.

Semantycznie nieuargumentowane, nagminne użycie kongruentnych przydawek oraz tendencja do stawiania związanej składnią zgody przydawki przed słowem określanym mogą doprowadzić do zaprzestania stosowania środków morfemowych w celu wyrażania atrybutywnej funkcji słowa precyzującego, co z kolei będzie oznaczać utratę związku zgody przydawki z określanym wyrazem i użycie

нисенко, С. Ю. Преображенский, М.А. Рыбаков, Системный взгляд как основа филологической мысли..., s. 171-302. 
rzeczownika zamiast kongruentnej przydawki przymiotnej. Przykładem są niepoprawne wyrażenia typu академия руководство czy дипломатия маэстро. Zestawienia atrybutywne będą przy tym upodobniać się do nazw złożonych, być może z możliwością włączenia podstawy imiesłowów przymiotnikowych, co z kolei spowoduje ograniczenie użycia zdań wtrąconych. W warunkach dużej społeczności językowej (megakolektywu) sytuacja ta doprowadzi do obniżenia kultury języka w społeczeństwie rosyjskim.

Cechą charakterystyczną odmiennych imiennych części mowy jest konsekwentne rozgraniczenie formalne i semantyczne rzeczownika i przymiotnika, które jest utrwalone zarówno w paradygmatach (formach morfologicznych), jak i charakterystyce gramatycznej jednostek słownikowych. Tworzenie formacji przymiotnikowych wymaga zastosowania określonych sposobów afiksacji - dobrze utrwalonych, zakorzenionych w systemie językowym, tym bardziej że z konkretnymi afiksami łączą się równie określone znaczenia, które odpowiednio przekształcają semantykę słowa w procesie derywacji słowotwórczej. Dla języków analitycznych natomiast charakterystyczny jest brak rozróżnienia między rzeczownikiem a przymiotnikiem. Problem ten jest sygnalizowany przez językoznawców i rozpatrywany z punktu widzenia zmian systemowych m.in. na podstawie wykorzystania obcego fleksyjnym językom słowiańskim modelu tworzenia złożonych nazw własnych - w istocie zestawień z członem określającym na pierwszym miejscu. Wymienić można rosyjskie nazwy nowych stadionów: Казанъ Арена, Балтика Арена, Волгоград Арена. We współczesnym języku rosyjskim nazwy tego typu pojawiają się pod wpływem języka angielskiego, lecz mogą być uznawane za bardziej naturalne ze względu na ich podobieństwo do produktywnego modelu złożeń rzeczownikowych. Jest to ciekawe zjawisko z pogranicza słowotwórstwa, fleksji i składni, którego omówienie wykracza poza ramy tego opracowania.

7. Naruszenie fleksyjności jest widoczne również w innego rodzaju konstrukcjach, z reguły nacechowanych ekspresywnie, a wykorzystywanych przede wszystkim w komunikowaniu medialnym. Należy do nich częste użycie przyimka no z celownikiem, które pozwala na znaczną kondensację treści. Np. w zdaniu: Норвежцы готовы помочь. Водолазы советуются по „Курску” („Известия” октябрь 2000; суt. za: Земская 2003).

Jelena Ziemska wskazany przykład opatrzyła komentarzem:

Необходимо добавить, что особая резкость нарушения нормы в конструкции советуются по „Курску” вызвана прагматическим фактором. 
Речь идет о национальной трагедии - гибели атомной подводной лодки „Курск.” Компрессия текста в этой ситуации выглядит не только как грамматически безграмотная, но и как вопиющее неуважение к чувствам людей ${ }^{24}$.

Zjawisko to, na które uwagę zwrócili językoznawcy pod koniec lat 90. ${ }^{25}$, nadal jest popularne, a o przydatności podobnych konstrukcji decyduje niewątpliwie wpisana w nie negatywność, jaką wyrażają, sugerowane wartościowanie, ale też skrótowość, jak w kolejnych przykładach w silnej pozycji tekstowej (w nagłówku): Кому в РФ и в мире невыгоден мир и сотрудничество по Украине (http://www. ng.ru/politics/2018-06-05/100_echoo4062018.html (7.08.2018)); Четыре державы решили особо не минсковать. Соглашения по Донбассу продлят на 2016 год [„Коммерсанть” 06.11.2015; http://kommersant.ru/doc/2849367 (6.12.2016)].

Obserwowane zmiany w zakresie fleksyjności w języku rosyjskim - w naszej ocenie zmierzające w kierunku jej ograniczenia - będące wynikiem pogłębiania się kulturowego zróżnicowania społeczności językowej przy zachowaniu takich parametrów zewnętrznych jak liczebność społeczności językowej oraz warunki komunikacji społecznej, nie tylko utrudnia wyrażenie złożonych sensów, ale przyczynia się również do ich niewykorzystywania przez uczestników komunikacji, obniżając tym samym ciągłość ważnych społecznie doświadczeń. Jeśli wyróżniki relacji i łączliwości między znakami przestają być społeczeństwu potrzebne, wówczas społeczność językowa zatraca możliwość odtwarzania i rozpoznawania znaków żywej mowy oraz utożsamiania ich z odpowiednimi komponentami treści (w istocie pozajęzykowymi procesami myślowymi, które jednak zostają ostatecznie ujęzykowione). Wskazane $\mathrm{w}$ artykule wybrane przykłady dowodzą, że zmiany fleksyjności naruszają również inne poziomy systemu językowego (fleksja $\rightarrow$ składnia $->$ semantyka $->$ spójność tekstu), zaburzając tym samym typologię systemową.

W języku rosyjskim fleksyjność - przy zachowaniu różnych mediów komunikacji - pozostaje częścią kultury języka i ciągłości przekazu. Formy gramatyczne, gatunki mowy, style funkcjonalne - poza słownictwem - składają się bowiem na tożsamość narodową, wpły-

${ }^{24}$ Е.А. Земская, Русский язык конца XX века: норма не запрет а выбор, w: Z. Rudnik-Karwatowa (red.), Procesy innowacyjne w językach stowiańskich..., S. 252.

${ }_{25}$ Por. М.Я. Гловинская, Изменения в морфологии и синтаксисе..., s. 203-232; Е.А. Земская, Русский язык конца ХХ века..., s. 245-257. 
wając na zachowania językowe. Fleksja jest więc kategorią potrzebną. Wprawdzie najbardziej tradycyjne ujęcie przewiduje rozpatrywanie wszelkich zmian - również w zakresie fleksji: form i połączeń wyrazów - w kategoriach normatywnych, zwykle innowacje traktując jako błędy, to zachowania językowe społeczeństwa będą decydować o tym, co winno być uznawane za wzorcowe, poprawne lub tylko dopuszczalne w określonym przedziale czasowym.

\section{БИБЛИОГРАФИЯ}

Bitsilli, Petr., ,Zametki o nekotorykh osobennostyakh razvitiya russkogo literaturnogo yazyka." 249-340. Bitsilli, Petr. Izbrannyye trudy pofilologii. Moskva: Naslediye, 1996 [Бицилли, Петр. „Заметки о некоторых особенностях развития русского литературного языка." 249-340. Бицилли, Петр. Избранные труды по филологии. Москва: Наследие, 1996].

Danylenko, Andriy. „The correlation of linguistic patterning and societal structures in systemic typology.” 81-96. Studia Linguistica Universitatis Iagellonicae Cracoviensis, 2018 t. 135.

Dremov, Aleksey. „Sistemnaya teoriya padezha i predloga v praktike prepodavaniya russkogo yazyka kak inostrannogo." 56-64. Mir russkogo slova. no 1-4 2001 [Дремов, Алексей. „Системная теория падежа и предлога в практике преподавания русского языка как иностранного.” 56-64. Мup русского слова. № 1-4, 2001].

Glovinskaya, Mariya. „Izmeneniya v morfologii i sintaksise..”203-232. Širjaev, Evgenij (Ed.). Russkiy yazyk. Najnowsze Dzieje Języków Słowiańskich. Gajda, Stanisław (Ed.). Opole: Wydawnictwo Uniwersytetu Opolskiego, 1997 [Гловинская, Мария. „Изменения в морфологии и синтаксисе..”203-232. Širjaev, Evgenij (Ed.). Русский язык. Gajda, Stanisław (Ed.). Najnowsze Dzieje Języków Słowiańskich. Opole: Wydawnictwo Uniwersytetu Opolskiego, 1997].

Gzgzyan, David. Funktsiya predloga vsostave semanticheskoy struktury vyskazyvaniya: avtoref. diss. ... kand. filol. nauk (10.02.01). Moskva: Universitetdruzhby narodov im. P. Lumumby, 1989. [Гзгзян, Давид. Функция предлога в составе семантической структуры высказывания: автореф. дисс. канд. филол. наук (10.02.01). Москва: Университет дружбы народов им. П. Лумумбы, 1989].

Humboldt, Wilhelm von. Über die Verschiedenheit des menschlichen Sprachbaues und ihren Einfluss auf die geistige Entwickelung des Menschengeschlechts. Berlin: Druckerei der Königlichen Akademie der Wissenschaften, 1836.

Kul'tura russkoy rechi. Trudy Instituta russkogo yazyka im. V.V. Vinogradova, vyp. 13. Shmelev, Aleksey (Ed.). Moskva, 2017 [Культура русской речи. Труды Института русского языка им. В. В. Виноградова, вып. 13. Шмелев, Алексей (Ed.). Москва, 2017.]

Melnikov, Gennadyi. Systemology and linguistic aspects of cybernetics. Amsterdam: OPA, 1988. 
Mel'nikov, Gennadiy. „Determinanta - vedushchaya grammaticheskaya tendentsiya yazyka.." 359-367. Fonetika, fonologiya, grammatika ( $v$ chest' 7o-letiya A.A. Reformat.kogo). Filin, Fedot (Ed.). Moskva: Nauka, 1971 [Мельников, Геннадий. „Детерминанта - ведущая грамматическая тенденция языка.” 359-367. Фонетика, фонология, грамматика (в честь 7о-летия А.А. РеФорматского). Филин, Федот (Еd.). Москва: Наука, 1971].

Mel'nikov, Gennadiy. Sistemnaya tipologiya yazykov: Sintez morfologicheskoy klassifikatsii yazykov so stadial'noy. Moskva: Izdatel'stvo RUDN, 2000 [Мельников, Геннадий. Системная типология языков: Синтезморфологической классификации языков со стадиальной. Москва: Издательство РУДН, 200о].

Mel'nikov, Gennadiy. Sistemnaya tipologiya yazykov: Printsipy, metody, modeli. Moskva: Nauka, 2003 [Мельников, Геннадий. Системная типология языков: Принципы, методы, модели. Москва: Наука, 2003].

Mel'nikov, Gennadiy, Dremov, Aleksey. „Urovnisvyaznosti teksta, aktual'naya predikatsiya i padezh s pozitsiy sistemnoy lingvistiki.” 49-70. Sintaksis i stilistika. Krylova, Ol'ga (Ed.). Moskva: Russkiy yazyk, 1984 [Мельников, Геннадий, Дремов, Алексей. „Уровни связности текста, актуальная предикация и падеж с позиций системной лингвистики." 49-70. Синтаксис и стилистика. Крылова, Ольга (Ed.). Москва: Русский язык, 1984].

Mieczkowska, Halina. „Formy zaniku fleksyjności w deklinacji słowackiej w konfrontacji z polszczyzną." 127-138. Procesy innowacyjne wjęzykach słowiańskich, Prace Slawistyczne 114. Rudnik-Karwatowa, Zofia (Ed.). Warszawa: SOW, 2003.

Miklosich, Franc. Vergleichende Grammatik der slawischen Sprachen. Bd. Syntax. Wien: W. Braumüller, 1868-1874.

Novyye tendentsii $v$ russkom yazyke nachala veka. Ratsiburskaya, Larissa (Ed.). Moskva: Izdatel'stvo „Flinta - Nauka.” 2014 [Новые тенденции в русском языке начала века. Рацибурская, Лариса (Ed.). Москва: Издательство „Флинта - Наука.” 2014].

Ovsyaniko-Kulikovskiy, Dmitriy.Sintaksisrusskogoyazyka.Sankt-Peterburg, Izdaniye D.Ye. Zhukovskogo, 1902 [Овсянико-Куликовский, Дмитрий. Синтаксис русского языка. Санкт-Петербург, Издание Д.Е. Жуковского, 1902].

Peshkovskiy, Aleksandr. Russkiy sintaksis v nauchnom osveshchenii. Moskva: Yazyki slavyanskikh kul'tur, 2001 [Пешковский, Александр. Русский синтаксис в научном освещении. Москва: Языки славянских культур, 2001].

Potebnya, Aleksandr. Iz zapisok po russkoy grammatike. T. 1. Khar'kov: D.N. Poluyekhtov, 1888 [Потебня, Александр. Из записок по русской грамматике. Т. 1. Харьков. Д.Н. Полуехтов, 1888].

Preobrazhenskiy, Sergey.,Sistemnyy analiz stikha.” 303-376. Valentinova, Ol'ga. Denisenko, Vladimir. Preobrazhenskiy, Sergey. Rybakov, Mikhail. Sistemnyy vzglyad kak osnova filologicheskoy mysli. Moskva: Yazyki slavyanskoy kul'tury, 2016 [Преображенский, Сергей.„Системный анализ стиха.” 303-376. Валентинова, Ольга. Денисенко, Владимир. Преображенский, Сергей. Рыбаков, Михаил. Системный взгляд как основа филологической мысли. Москва: Языки славянской культуры, 2016].

Pstyga, Alicja. „Problemy interpretacji tekstu: integracja metodologiczna we współczesnym językoznawstwie słowiańskim.” 103-111. Wspótczesne językoznawstwo stowiańskie. Teoria i metodologia badań. T. 2: Metody analizy i opisu jednostek leksykalnych i tekstowych. Red. Koriakowcewa, Elena. Siedlce: Wydawnictwo UPH w Siedlcach, 2016. 
Rybakov, Mikhail. „Razvitiye predstavleniy o tipologicheskom skhodstve yazykov: ot mnogomernoy klassifikatsii E. Sepira do sistemnoy tipologii G.P. Mel'nikova." 17-136. Valentinova, Ol'ga. Denisenko, Vladimir. Preobrazhenskiy, Sergey. Rybakov, Mikhail. Sistemnyy vzglyad kak osnova filologicheskoy mysli. Moskva: Yazyki slavyanskoy kul'tury, 2016 [Рыбаков, Михаил. „Развитие представлений о типологическом сходстве языков: от многомерной классификации Э. Сепира до системной типологии Г.П. Мельникова." 17136. Валентинова, Ольга. Денисенко, Владимир. Преображенский, Сергей. Рыбаков, Михаил. Системный взгляд как основа филологической мысли. Москва: Языки славянской культуры, 2016].

Valentinova, Ol'ga. „Sistemnyy podkhod k issledovaniyu teksta i stilya.” 171-302. Valentinova, Ol'ga. Denisenko, Vladimir. Preobrazhenskiy, Sergey. Rybakov, Mikhail. Sistemnyy vzglyad kak osnova filologicheskoy mysli. Moskva: Yazyki slavyanskoy kul'tury, 2016 [Валентинова, Ольга. „Системный подход к исследованию текста и стиля.” 171-302. Валентинова, Ольга. Денисенко, Владимир. Преображенский, Сергей. Рыбаков, Михаил. Системный взгляд как основа филологической мысли. Москва: Языки славянской культуры, 2016].

Valentinova, Ol'ga, Rybakov, Mikhail. „Tipologicheskaya dinamika yazyka kak rezul'tat izmeneniya mental'nosti yego nositeley.” 58-70. Yazyk i mental'nost' $v$ diakhronii: Materialy Vserossiyskogo nauchnogo seminara. Ed. Mariya, Pimenova. Vladimir, 2017 [Валентинова, Ольга, Рыбаков, Михаил. "Типологическая динамика языка как результат изменения ментальности его носителей." 58-70. Язык и ментальность в диахронии: Материалы Всероссийского научного семинара. Ред. Пименова, Мария. Владимир, 2017].

Valentinova, Ol'ga, Rybakov, Mikhail, Pstyga, Alitsiya. „Tipologicheskaya sokhranennost' russkogo yazyka kak neobkhodimoye usloviyekul'turnoy i intellektual'noy samoidentifikatsii rossyskogo obshchestva." 418-428. Voprosy teorii i praktiki zhurnalistiki (Theoretical and Practical Issues of Journalism). t. 7, no 3, 2018 [Валентинова, Ольга. Рыбаков, Михаил. Пстыга, Алиция. „Типологическая сохраненность русского языка как необходимое условие культурной и интеллектуальной самоидентификации россйского общества." 418-428. Вопросы теории и практики журналистики (Theoretical and Practical Issues of Journalism). T. 7, № 3, 2018].

Zemskaya, Yelena. „Russkiy yazyk kontsa XX veka: norma ne zapret a vybor.” 245257. Procesy innowacyjne w językach stowiańskich. Prace Slawistyczne 114. Ed. Rudnik-Karwatowa, Zofia. Warszawa: SOW, 2003 [Земская, Елена. „Русский язык конца XX века: норма не запрет а выбор.” 245-257. Procesy innowacyjne $w$ językach stowiańskich. Prace Slawistyczne 114. Rudnik-Karwatowa, Zofia (Ed.). Warszawa: SOW, 2003]. 
NARUSZENIE FLEKSYJNOŚCI...

Ольга И. Валентинова, Михаил А. Рыбаков, Алиция Пстыга

РАЗРУШЕНИЕ ФЛЕКТИВНОСТИ СОВРЕМЕННОГО РУССКОГО ЯЗЫКА

С ПОЗИЦИЙ СИСТЕМНОЙ ТИПОЛОГИИ ЯЗЫКОВ

ГЕННАДИЯ П. МЕЛЬНИКОВА

Резюме

Авторы статьи предлагают анализ и оценку происходящих в современном русском языке явлений, приводяхих к разрушению флективности с позиций системной типологии языков Г.П. Мельникова. Внешнее сохранение флексии и грамматического согласования при нарушении функции прогноза в обозначении причинно-следственных связей развивающегося события не свидетельствует о флективности.

Ol'ga I. Valentinova, Mikhail A. Rybakov, Alicja Pstyga

VIOLATION OF FLECTIONALITY IN CONTEMPORARY RUSSIAN LANGUAGE FROM THE STANDPOINT

OF GENNADY P. MELNIKOV’S SYSTEMIC TYPOLOGY OF LANGUAGES

Summary

The authors of the article discuss from the standpoint of the G.P. Melnikov's systemic typology of languages the phenomena characteristic for speech works of all functional styles of the modern Russian literary language that indicates violation of flectionality of the Russian language. The external preservation of inflexion and grammatical coordination in the event of violation of the forecast function in the designation of cause-effect relationships of the developing events, does not indicate flexiveness. 